\title{
ACID MINE-WATER AND AGRICULTURAL POLLUTION IN A RIVER SKIRTING THE DOÑANA NATIONAL PARK (GUADIAMAR RIVER, SOUTH WEST SPAIN)*
}

\author{
F. Cabrera, C. G. Toca, E. Diaz and P. de Arambarri \\ Centro de Edafologia y Biologia Aplicada del Cuarto, Apartado 1052, Sevilla, Spain
}

\begin{abstract}
Abstrect-An inventory of the pollution originated by a mining industry in its first stages of development and by a highly developed agriculture is carried out in a river skirting the Donana National Park.

The pathway along the Guadiamar river basin was studied for heavy metals derived from the opencast-worked polymetallic sulphide deposits and from the mine spoil heaps. The dynamics of $N, P$ and herbicides in waters of urban and/or agricultural origin was also discussed.
\end{abstract}

Key words-acid mine water, agricultural pollution, alpechines (olive oil mill effluents), Doñana National Park, heavy metals

\section{INTRODUCTION}

South-west Spain is rich in sulphide deposits of different kinds some of them exploited since biblical times. Near the village of Aznalcóllar (Seville province) there are pyrite outcrops rich in zinc, lead, copper and manganese worked with different success. From 1977 to 1979,12 million metric tons of mineral were extracted and a new factory was built to treat and concentrate the pyrites. In a second stage a sulphuric acid factory will be built to transform 2 million metric ton $\mathrm{yr}^{-1}$ of floated pyrite (Andaluza de Piritas, 1978).

The Agrio river receives the drainage waters from Aznalcóllar opencast-worked polymetallic sulphide deposits and the old mine spoil heaps. Some $7 \mathrm{~km}$ downstream, the Agrio river joins the Guadiamar river which is the last tributary on the right of the Guadalquivir river, the most important andalusian course of water. In its last $60-70 \mathrm{~km}$ the Guadalquivir river is a low-land navigable river with large tidal influence.

The Guadiamar river and all its tributaries stop flowing in the dry season which normally extends from May-June to September-October, although the rivers do not stop flowing till the end of June (Vanney, 1970). For this reason, the Agrio river has recently been dammed up near Aznalcóllar and its waters are used for processing the pyritic mineral. This has changed the normal water regime of the zone.

The Guadiamar river runs across an ample agricultural region where the northern part is devoted to dry-land agriculture, irrigated fruit and olive tree orchards. In this area there are olive-oil manufacturing mills and some other smaller industries related to olive, wine and fruit which effluents are discharged untreated to the water courses. Figure I shows the location of the more important outlets. Downstream, an area of some 20,000 ha of reclaimed marsh soils standing rice as the only crop, extends between the southern left bank of the Guadiamar river and the right bank of the Guadalquivir river. The rice mean yield in this waste area is near 6 metric ton $\mathrm{ha}^{-1}$ supposedly the highest in the world.

The southern right bank of the Guadiamar river includes the marshy part of Doñana National Park which extends westwards to the sea as shown in Fig. 2.

The utmost importance of Doñana National Park, which was founded by the World Wildlife Fund, is well known. Nowadays, the Donana National Park is isolated from the waters of the Guadiamar river by means of levees ("A" in Fig. 2). However, water from the Guadiamar and Guadalquivir rivers can enter the Park at high tide levels across the spots indicated by arrows in Fig. 2, at the end of the levees.

It is suspected that the levees of the Guadiamar river are altering the water regime of the Donana National Park marshes causing drought and other problems of ecological significance. For this reason there exists a project to open the levees somewhere near point " $B$ " in Fig. 2 and allow the waters of the Guadiamar river to flood the marshes of the Doñana National Park again.

Guadiamar river catchment supports a total population of approx. 40,000 living in villages which sewage outlets are discharged untreated to the river. The Guadalquivir river, just after receiving the Guadiamar river, flows into the sea at Cadiz Gulf. Cadiz Gulf is rich in high quality shell-fishes and touristic resorts which are undoubtedly affected by the pollution.

The preceding description shows the importance of assessing the presence of pollutants from mine, olive- 
oil mills, intensive agriculture and village sewages $n$ the water courses of the region. The present work wals made with this aim and carried out during 1978 and 1979 when the extraction of mineral from Aznalcollar mine had just started again. Concentration and pro- cessing of the mineral began only in late 1979. This study can be looked upon as an inventory of the pollution originated by a mining industry in its first stages of development and by a highly developed. very specialized agriculture.

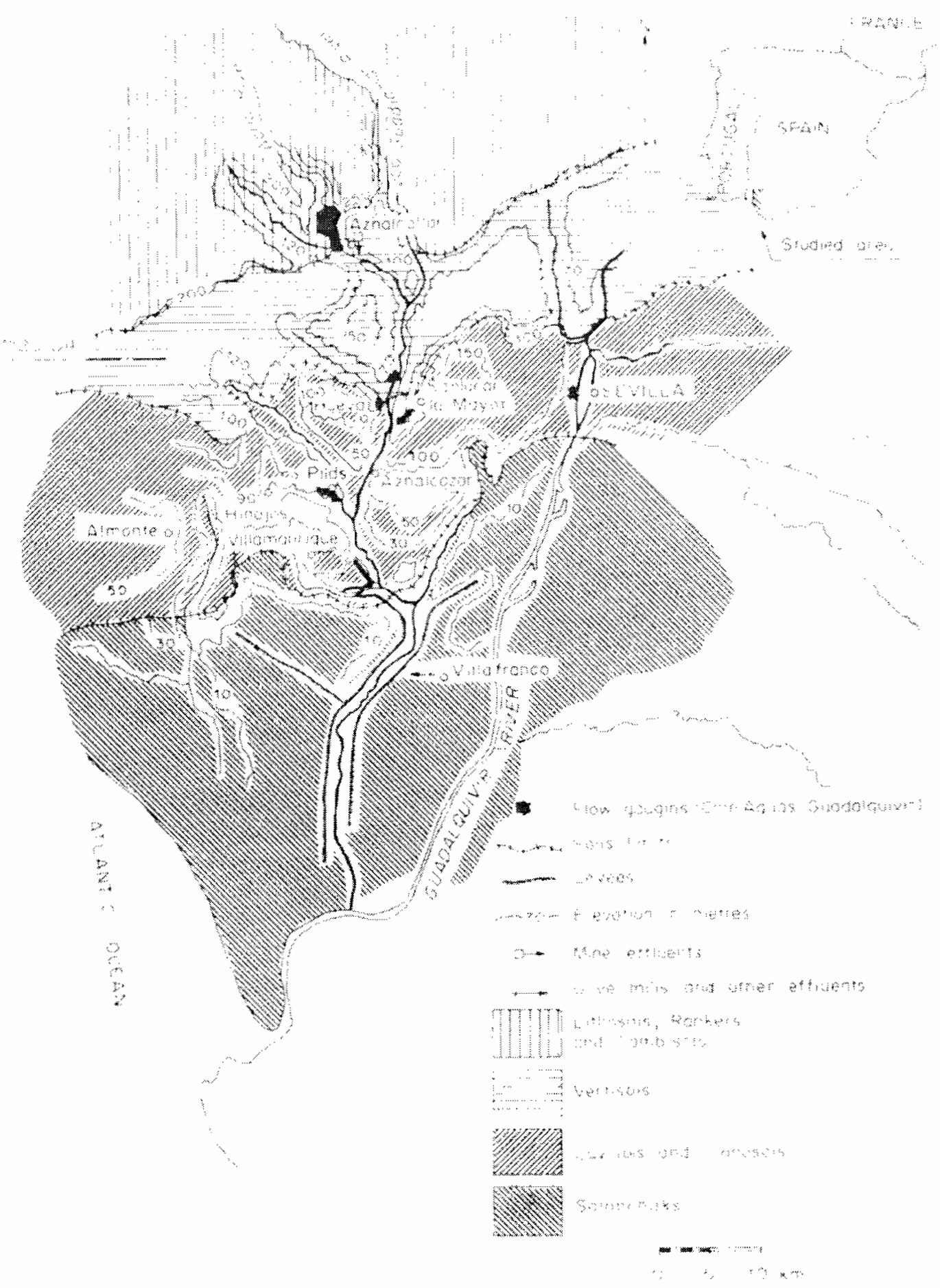

Fig. 1. Study area showing topography, soil distribution and location of the main waste effluents. 


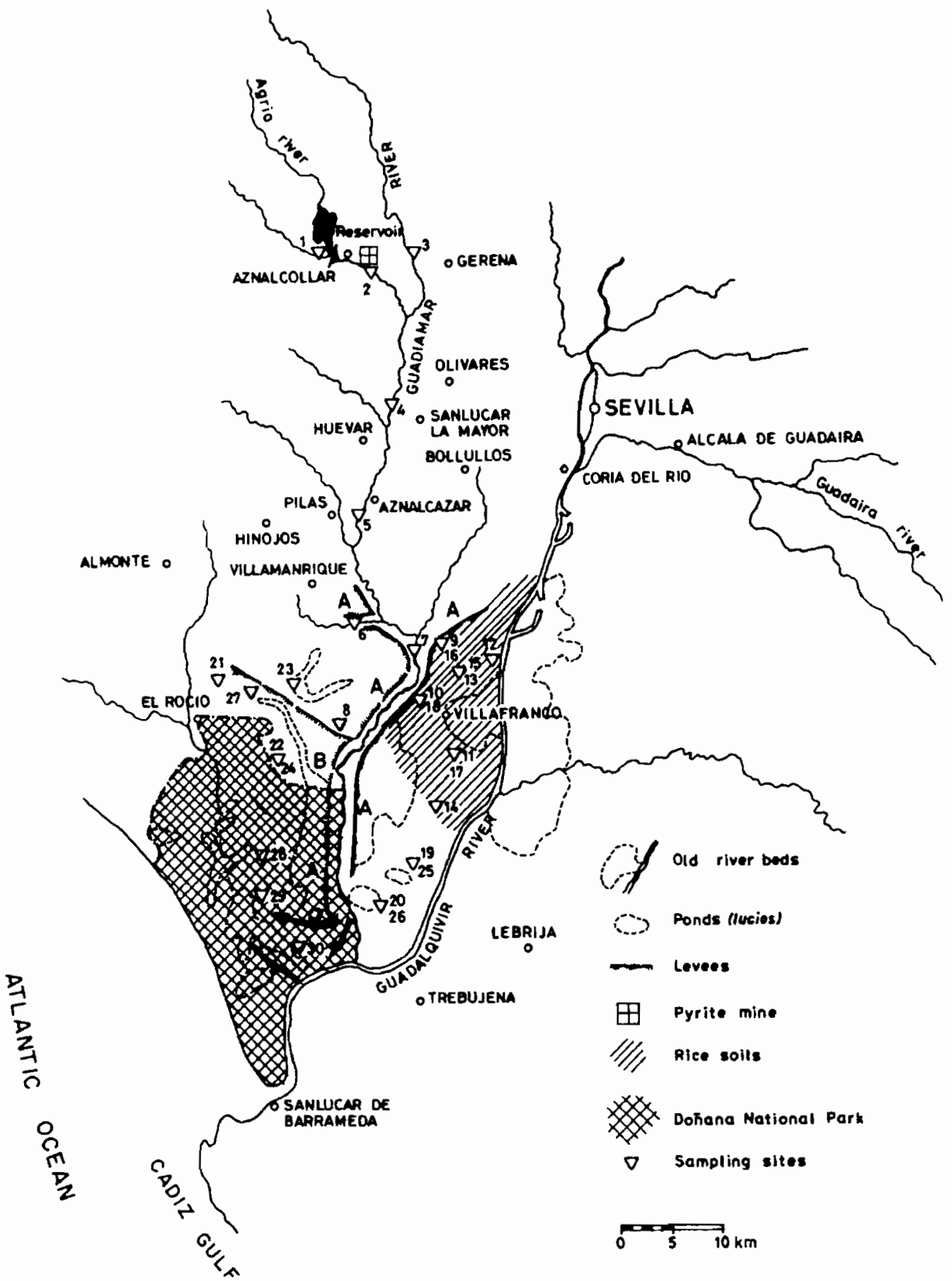

Fig. 2. Study area showing location of sampling sites.

\section{MATERLALS AND METHODS}

Sampling sites and description of the area

Location of sampling sites are shown in Fig. 2. Sampling site 1 is on the Agrio reservoir upstream from the mine influence. Site 2 is on the Agrio river downstream from the sulphide deposits and the waste effluent of the processing factory. Sites 3 and 4,5 and 7 are situated respectively before and after the confluence of the Agrio river with the Guadiamar river. Sites 4,5 and 7 are the most affected by the effluents from olive-oil mills and village sewages. Sampling sites 6 and 8 are near the confluences of the Gua- diamar river with two canals collecting drainage waters from marsh soils under reclamation. Site 6 also receives the influence of dry-land agriculture and villages. Sampling sites $9,10,11$ and 13 are on rice field drains and sites 12 is on the Guadalquivir river.

Water samples from sites 1 to 13 were collected 48 times during 1978 and 1979, approximately every fortnight.

Additional sampling sites 14 and $19-23$, situated on marshes, were sampled for water and sites 24-27, situated on shallow ponds of salty water (lucios) of the Doñana National Park, were sampled for sediments in September 1978 and 1979. Samples of water from sites 15-18, located 
on the rice field, and $28-30$, on the lucios, were collected in June and July 1979 for pesticides determinations.

Sampling sites 1,2 and 3 were located on mountain. poorly developed soils (Lithosols, Rankers and Cambisols on slates and schists and Dystric Cambisols on spilites). Sites 4,5 and 7 are in a different scenery of small. round topped hills. Site 4 is surrounded by Chromic Vertisols and Vertic Cambisols developed on marls and Calcareous marls. Sampling sites 5 and 7. located on Calcareous Fluvisols and on Alluvial sediments, are surrounded by Chromic Luvisols on calcarenites, Planosols and calcareous sediments.

All remaining sampling sites are located on flat open marshes with gleyc and takinic Solonchaks on fluvio-marine clay sediments (Centro de Edafologia, 1979). Figure I shows the distributon of the main groups of soils.

As previously mentioned, the flow of Agrio and Guadiamar rivers changes very much depending on the contrasting Andalusian weather. Table 1 shows mean monthly flows of the Guadalquivir and Guadiamar rivers mean monthly discharge of the Agrio reservoir as well as the monthly rainfall in the region during the 2 years of study. A dry and a wet period may be considered, a dry period extending over May-September (cumulative rainfall $48.8 \mathrm{~mm}$ in 1978 and $14.0 \mathrm{~mm}$ in 1979), and a wet period comprising from January to April and from October to December (cumulative rainfall $368.3 \mathrm{~mm}$ in 1978 and $509.4 \mathrm{~mm}$ in 1979).

Water temperature changes from 9 to $31 \mathrm{C}$ being the $20 \%$ of the recorded values $\geqslant 25^{\circ} \mathrm{C}$. The mean air temperature varies from 4.7 C, January 1978 and $5.8^{\circ} \mathrm{C}$, December 1979 , to $35.2 \mathrm{C}$, July 1978 and $34.8^{\circ} \mathrm{C}$, August 1979. Maximum temperatures during summer were $42.6^{\circ} \mathrm{C}$ in 1978 and 41. $0^{\circ} \mathrm{C}$ in 1979. Minimum temperature was $-1.0 \mathrm{C}$ in both winters.

\section{Analytical methods}

Water samples were surface collected in polythene acidwashed bottles and stored at $4^{\circ} \mathrm{C}$ before analysis.

Dissolved oxygen was determined by the azide modification of the Winkler method (APHA, 1971) on water samples collected in glass bottles and fixed in silu.

Measurement of $\mathrm{pH}$ of unfiltered waters were made in laboratory using a glass- $\mathrm{Ag} / \mathrm{AgCl}$ combination electrode.

Total phosphorus and total Kjeldahl nitrogen were determined after digesting unfiltered samples by the method outlined by Nichols (1975) and modified by Cabrera et al. (1981). Total phosphorus in the digest was determined as ortho-phosphate by the Murphy and Riley method (1962). Total Kjeldahl nitrogen as ammonia was determined by the method of Nessler (APHA, 1971) or by the Solorzano method (1969).

Potassium permanganate-consuming capacity ( $\mathrm{PCCC}$ ) of unfiltered waters was determined by the method described by Rodier (1971).

Dissolved phosphorus, ammonia, nitrate and nitrite were determined in filtered samples. Phosphorus and ammonia were analysed by the methods referred to above, and nitrate and nitrite by the method of Scheiner (1974) and Stainton et al. (1977) respectively.

Potassium, iron, copper, manganese, lead and zinc were determined in filtered samples. Potassium was analysed by emmission spectrophotometry and $\mathrm{Fe}, \mathrm{Cu}, \mathrm{Mn}, \mathrm{Pb}$ and $\mathrm{Zn}$ by flame atomic absorption spectrophotometry. Determination of $\mathrm{Fe}, \mathrm{Cu}, \mathrm{Mn}, \mathrm{Pb}$ and $\mathrm{Zn}$ required sometimes the previous concentration of the samples by evaporation to dryness and subsequent dissolution of the residue with $2 \%$ conc. $\mathrm{HCl}$ (U.S. EPA, 1979).

Dissolved and suspended solids were obtained by filtering known volumes of water through preignited Whatman GF/C glass fibre filter paper and evaporating the filtrates. Evaporated filtrates and filters were heated up to constant weight at 110 and later at $525^{\circ} \mathrm{C}$. Dissolved inorganic solids (d.i.s.) were considered to be the residue of the filtrate at

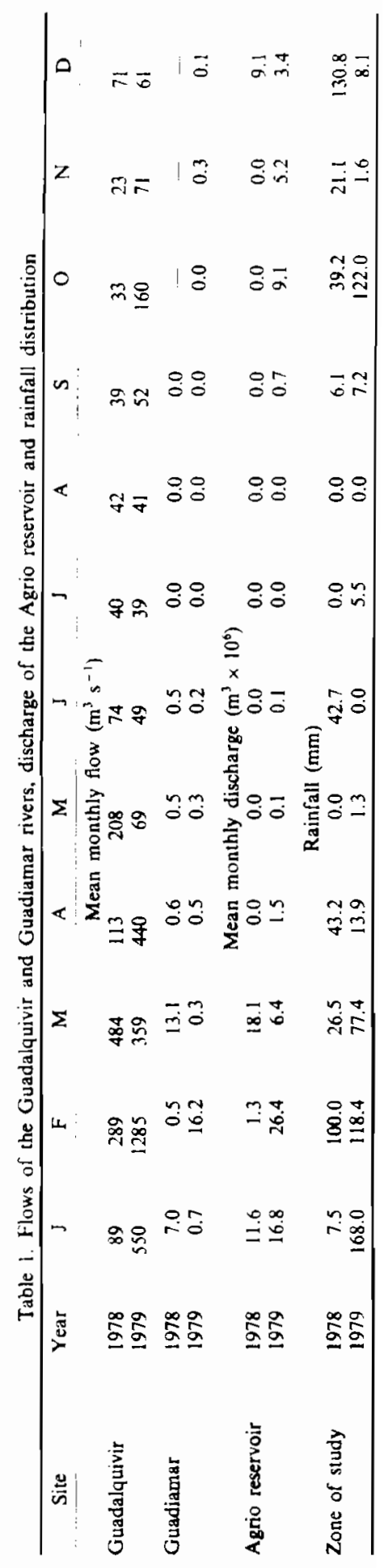


$525^{\circ} \mathrm{C}$, and dissolved organic solids (d.o.s.) were calculated by difference between weights at 110 and $525^{\circ} \mathrm{C}$. Suspended inorganic solids (s.i.s.) and suspended organic solids (s.o.s.) were calculated in a similar way from the weights of the filters.

For the herbicide Ordram or Molinate (5-ethyl hexahydro-1H-azepine-1-carbothionate) determination, unfiltered waters were acidulated with conc. $\mathrm{HCl}$ and extracted with hexane (Zweig and Sherma, 1972). For the determination of the Chlorophenoxy herbicides 2,4-D(2,4-dichlorophenoxy acetic acid) and 2,4,5-TP (2-2,4,5-trichlorophenoxy propionic acid), unfiltered waters acidulated with conc. $\mathrm{H}_{2} \mathrm{SO}_{4}$ were extracted with dichloroethane and methylated with diazomethane (Chacko and Gummer, 1980). Herbicide extracts were analysed by liquid-gas chromatography using lindane (gamma isomer of the hexachlorocyclohexane) as internal standard.

Samples of superficial sediments were air-dried and ground to pass a $0.5 \mathrm{~mm}$ sieve. Analysis of their $\mathrm{Fe}, \mathrm{Cu}$, $\mathrm{Mn}, \mathrm{Pb}$ and $\mathrm{Zn}$ contents were carried out by flame atomic absorption spectrophotometry after $\mathrm{HNO}_{3}-\mathrm{HClO}_{4}$ digestion of the ground samples.

\section{RESULTS AND DISCUSSION}

\section{Mining pollution}

Figure 3 shows the mean values of $\mathrm{pH}$, heavy metals and suspended inorganic solids (s.i.s.) contents in sampling sites $1,2,3,4,5,7$ and 12 during wet and dry periods of 1978 and 1979. The corresponding standard deviations (not shown) are of the same order as the mean values. The time distribution of some of the considered parameters shown in Figs 4, 5 and 6 gives their variation ranges.

Sites 1,3 and 12 , beyond the influence of the pyrite deposits, the spoil heaps and the mineral processing factory, show $\mathrm{pH}$ values and heavy metal concentrations within the range of the U.S. EPA (1977) quality criteria. Low levels of heavy metals in the Guadalquivir river (site 12) is of great importance because its waters are used for flooding the rice fields. Consequently, heavy metal contents in water of the rice fields and irrigation canals (data not shown here), represented by sites $9,10,11$ and 13 (Fig. 2) are of the same order as those in the waters of the Guadalquivir river. In a few occasions, as will be shown later, this is not true because water from the Guadiamar river was pumped into sampling site 10 .

The s.i.s. contents in site 12 are higher in wet than in dry period mainly due to the runoff of the agricultural smectitic rich soils in the middle course of the Guadalquivir river, and to a lesser extent due to the resuspension of deposited sediments.

In general, sites 2, 4, 5 and 7 show heavy metal concentrations higher than those in sites 1,3 , and 12 , showing the influence of the polymetallic sulphide deposits.

The oxidation of sulphides upstream of site 2 causes the high pollution by heavy metals and the low $\mathrm{pH}$ and dissolved oxygen values (Thompson, 1980). The higher values of $\mathrm{pH}$ and dissolved oxygen in site 4 could mean that those oxidation reactions have taken place before this site (Table 2). The dissimilarities between sites 2 and 4 are further evidenced from Fig. 4 which shows the variation along the 2 years of study of the PPCC and Fe content in both sampling sites. In site 2 PPCC and Fe curves show a similar pattern from mid-summer 1978 onwards, corresponding in time with the start of the high scale mineral extraction. Correlation between PPCC and Fe can be explained accepting that PPCC values reflect the presence of reduced ionic species in water (i.e. $\mathrm{Fe}^{2+}$ ). The different pattern of PPCC and $\mathrm{Fe}$ in site 4 shows on the other hand that the oxidation processes of reduced inorganic species practically come to an end before this sampling site.

Changes in flow of Agrio and Guadiamar rivers have important effects on the pollution of the sampling sites located downstream of site 2. During wet period of 1978 and 1979 the Agrio reservoir had to be discharged (Table 1 and Fig. 5) causing dramatic changes in the flows of both Agrio and Guadiamar rivers and abrupt changes in the dissolved metal contents (see Fig. 4 for Fe variations), in t.i.s. and pH values of sampling site 2 (Fig. 5). Minimum values of t.i.s. in site 2 appear at high pH values and correspond with heavy rainfall and/or reservoir releases (Fig. 5).

Table 3 shows the $\mathrm{pH}$ values and contents in $\mathrm{Fe}$ and total and suspended solids of water sampled immediatedly before and after two marked increases in flow of Agrio and Guadiamar rivers. This data corresponds with two of the most conspicuous minima shown for site 2 in Fig. 5. Site 1 only shows an increase of total organic solids (t.o.s. $=$ d.o.s. + s.o.s.) in the high flow periods possibly due to runoff of the vegetable cover of the poorly developed soils of the area. The arrival of the reservoir-discharged water to site 2 produces a sharp increase in $\mathrm{pH}$ and a decrease of the $\mathrm{Fe}$ and t.i.s. contents. The increase of flow resuspends river sediments, carrying them downstream and increasing the contents in metal and suspended matter as shown by Symader (1980) elsewhere. Accordingly, site 4, 5 and 7 show a proportionally important increase in the contents of metals, s.i.s. and t.o.s. in high flow periods (Table 3 ).

Total inorganic solids in sites 3 and 4 , located before and after the mine effluent outlets respectively, shows less rainfall or reservoir release dependence than site 2 (Fig. 5) and small changes of $\mathrm{pH}$ values (site 3: $\max .8 .4$, min. 7.3 , mean value 7.9 ; site 4 : $\max$. 8.5 , min. 7.2 , mean value 7.9 ). On the other hand it can be deduced from Fig. 5 that t.i.s. in site 7 are independent of both rainfall and water $\mathrm{pH}$; maximum values of t.i.s. will be commented later.

Results in Figs 3 and 4 indicate that most of the suspended or dissolved metals coming from the mine effluents are sedimented or precipitated before site 4 , which is plainly shown by the appearance of the so-called "yellow boy" and other hydrous oxides on the Agrio and Guadiamar river beds. Precipitation is mainly caused by the neutralization of water due to the change of the soil parent materials from acid to 


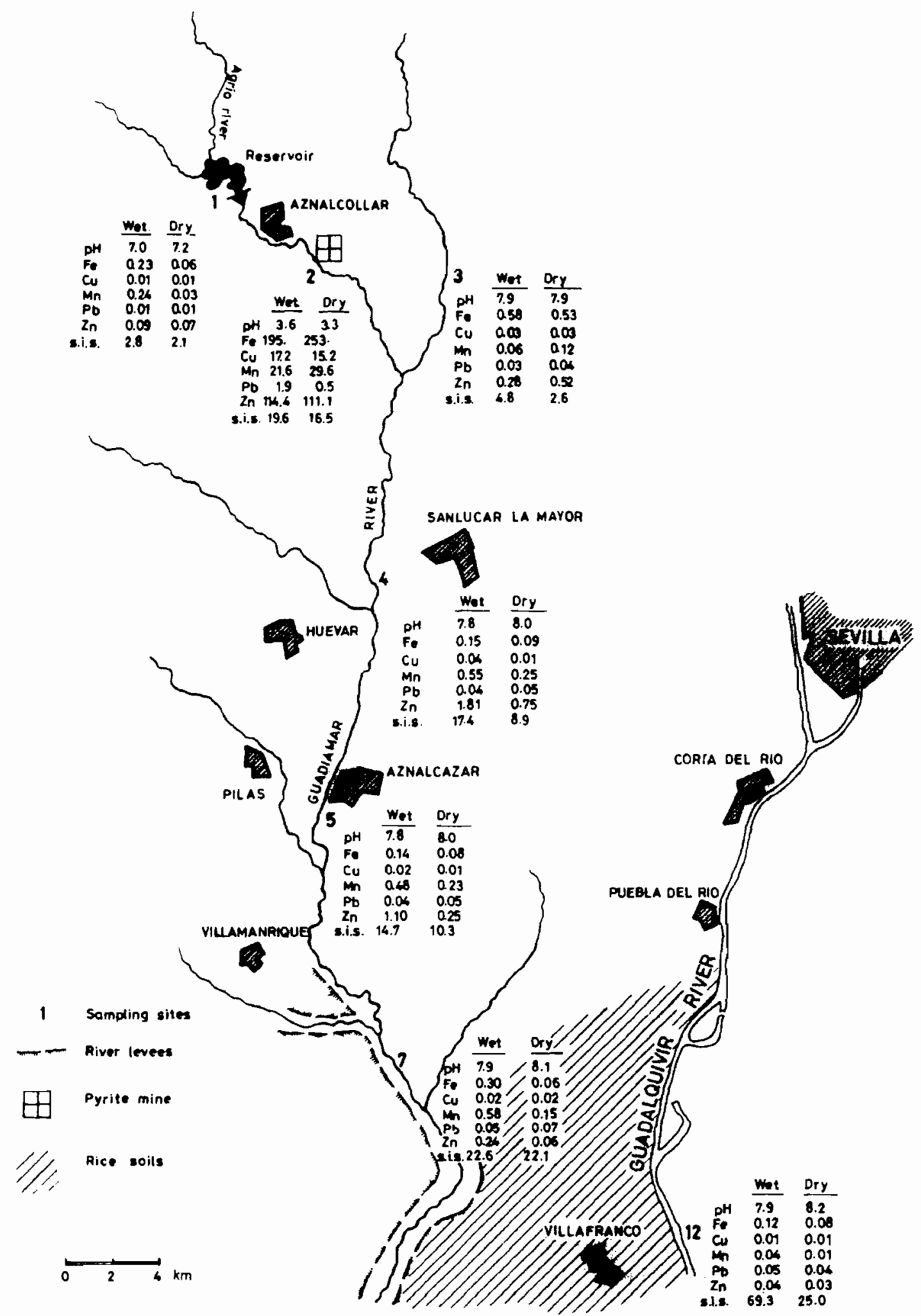

Fig. 3. Mean values of $\mathrm{pH}$, heavy metals and suspended inorganic solid (s.i.s.) contents in sampling sites $\mathrm{I}, 2,3,4,5,7$ and 12 during wet and dry periods of 1978 and 1979 (concentrations in $\mathrm{mg} \mathrm{I}^{-1}$ ).

calcareous along the Guadiamar river basin just after joining the Agrio river (Fig. 1). Dilution of acid mine effluents by water from Agrio reservoir and Guadiamar river also contributes to the water neutralization.
Water neutralization causes the concentration of $\mathrm{Fe}, \mathrm{Cu}$ and $\mathrm{Pb}$ in solution to decrease downstream from site 2 up to the levels found in the Guadalquivir river (site 12, out of the influence of the mine) (Fig. 3). Manganese and $\mathrm{Zn}$ concentrations also decrease 
Table 2. Values $\mathrm{pH}$ and dissolved oxygen in sampling sites 2 and 4 during 1978 and 1979

\begin{tabular}{cccccccc}
\hline \multirow{2}{*}{$\begin{array}{c}\text { Sampling } \\
\text { site }\end{array}$} & \multicolumn{3}{c}{$\mathrm{pH}$} & & \multicolumn{3}{c}{$\begin{array}{c}\text { Dissolved oxygen } \\
\left(\mathrm{mg} \mathrm{O} \mathrm{O}^{-1} \text { ) }\right.\end{array}$} \\
\cline { 2 - 7 } & Mean & Max. & Min. & Mean & Max. & Min. \\
\hline 2 & 3.5 & $7.5^{*}$ & 2.7 & 2.7 & $12.8^{*}$ & 0 \\
4 & 7.9 & 8.5 & 7.2 & 9.5 & 13.3 & 6.5 \\
\hline
\end{tabular}

"Exceptional values registered in winter 1979 during a reservoir discharge

downstream but their values in site 7 are still 12 and 6 times respectively those in site 12 . The same differential behaviour of these metals was found by other workers (Norris et al., 1981; Young and Blevins, 1981; Filipek et al., 1981).

Generally in wet periods mean concentrations of heavy metals in waters from sites 4,5 and 7 (Fig. 3) are higher than expected from the respective hydrous oxide solubilities (Pagenkoff and Cameron, 1979). This fact can be explained accepting that heavy rains and water discharges from the Agrio reservoir not only cause the resuspension of the sediments but also the appearance of organic and inorganic complexing agents which alter the normal precipitation-adsorption pathway of deposition of metals into the sediments.

On the other hand, in autumn the olive-oil manufacturing mills start working and their effluents called alpechines enter into the river without treatment through points shown in Fig. 1, giving a noticeable black colour to the water. The alpechines have high $\mathrm{K}, \mathrm{P}$ and organic matter contents (average $\mathrm{BOD}_{5}$
$33,000 \mathrm{mg} \mathrm{1}^{-1}$ ) (Fiestas et al., 1979). Alpechines organic matter are rich in polyphenols which are known to be active chelating agents. The biggest olive-oil mill of this zone is in the village of Pilas and its effluents (approx. $3 \times 10^{4} \mathrm{~m}^{3}$ total discharge, in the grinding season which lasts from October to January) are discharged into the Guadiamar river between sampling sites 5 and 7 . Figure 6 shows two noticeable peaks of $\mathrm{K}$ in site 7 and only a smaller one in site 5 . Potassium peaks are supposed to show the relative importance of the alpechines presence in site 5 and 7 . If that is so, the increase of $\mathrm{Fe}$ and $\mathrm{Mn}$ in solution shown in Fig. 6 must be due to the complexing action of alpechines. From December to March 1978 there is no available data for site 7 (Fig. 6) because the Guadiamar flood cut the land access to this sampling site.

Before the levees marked "A" in Fig. 2 were built, the Guardiamar river entered into the Donana $\mathrm{Na}$ tional Park and the heavy metal polution reached as far as sampling sites 24,25 and 26 (Fig. 2). This is shown by the fact that sediments in sites 24,25 and 26 are richer in metals than both the soils of the Guadalquivir marshes (Aubert and Pinta, 1977) and sediments at site 27 , the latter being located near to, but out of reach of the effect of the Guadiamar river floods (Table 4). Despite that sites 24-26 are located about $50 \mathrm{~km}$ downstream from the mine, the found metal contents are even higher than values given by other workers for sediments close to similar pollution sources (Hutchinson and Whitby, 1974; Moore, 1980; Say and Giami, 1981; Norris et al., 1981).

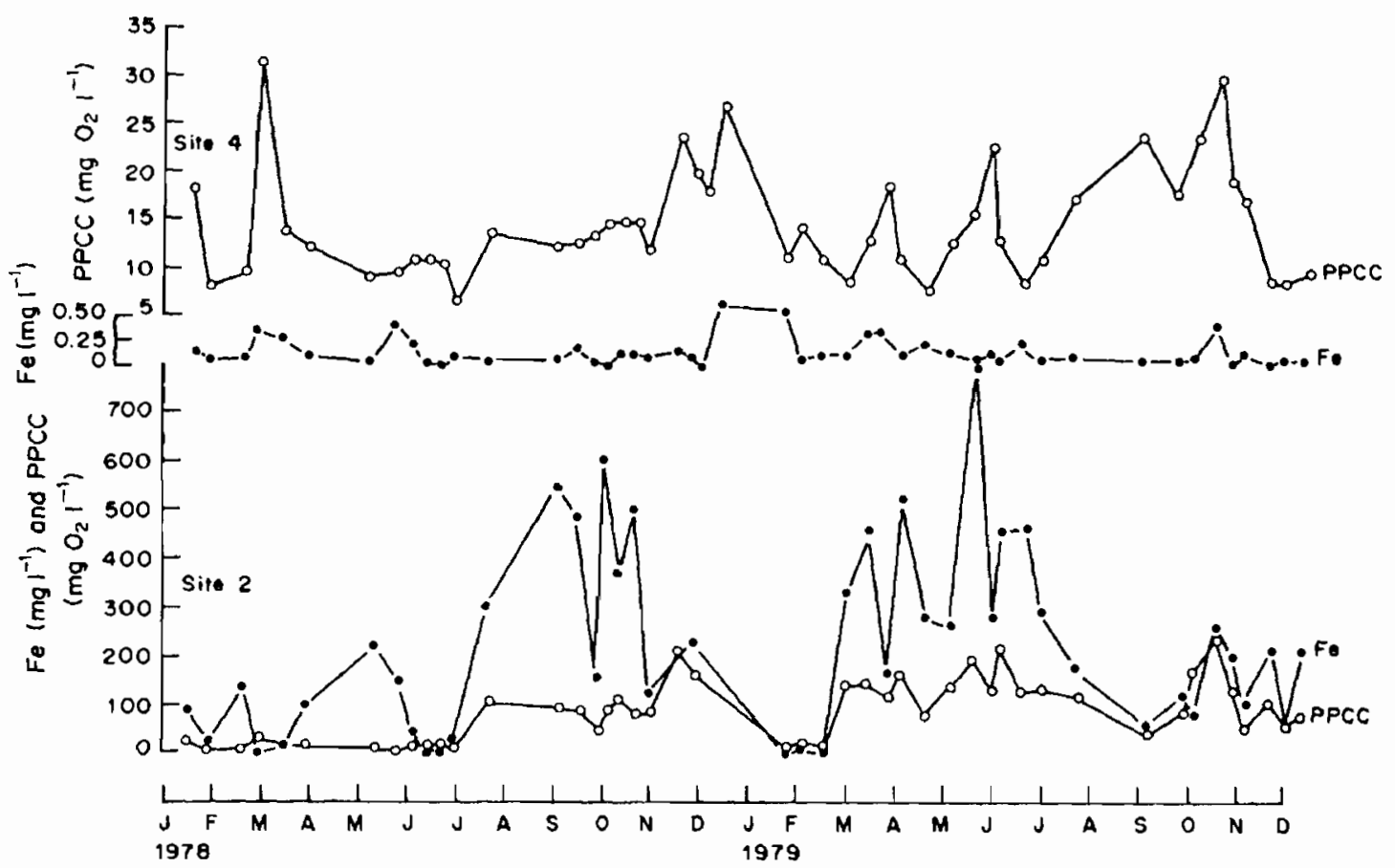

Fig. 4. Variations of Fe concentration and potassium permanganate consuming capacity (PPCC) in sampling sites 2 and 4 during 1978 and 1979. 


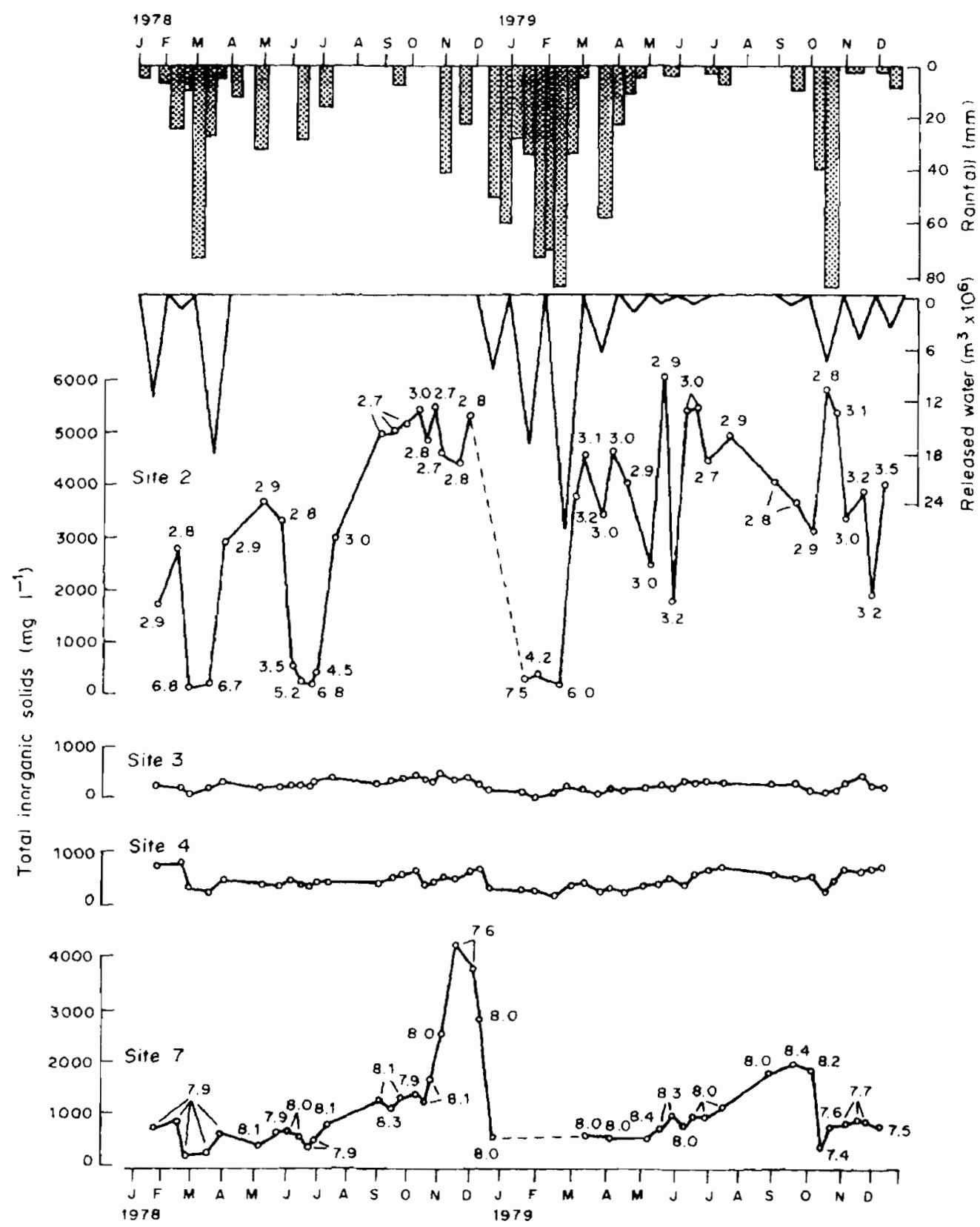

Fig. 5. Variations of total inorganic solid (t.i.s.) contents and $\mathrm{pH}$ in sampling sites 2, 3,4 and 7, rainfall and reservoir discharge during 1978 and 1979. Figures near the experimental points are $\mathrm{pH}$ values (concentrations in $\mathrm{mg} \mathrm{|}^{-1}$ ).

\section{Agricultural pollution}

As described above olive-oil mill wastes called alpechines are discharged into the Guadiamar river causing a pollution that may be considered of agricultural origin. The presence of alpechines in water of site 7 during October-December 1978 decreases the dissolved oxygen content and increases the PPCC and the t.o.s., K, Fe and Mn contents (Fig. 6). The peak of ti.s. for site 7 in winter 1979 (Fig. 5) is also related to the alpechines appearance. As a result of the alpechines pollution, the fish population dies every year in the lower course of the Guadiamar river, particularly in the zone between levees. On the other hand, these polluted waters can enter the National Park of Doñana as a consequence of the high tide and floods. It has been also observed that waters from Guadiamar river were sometimes pumped into a nearby rice field irrigation canal (sampling site 10); consequently, in autumn, the olive grinding season, concentrations of $\mathrm{Fe}, \mathrm{Mn}, \mathrm{Zn}$ and $\mathrm{K}$ as well as PPCC in site 10 are higher than in spring, while the dissolved oxygen values are lower (Table 5).

Another source of pollution to be considered on the lower course of the Guadiamar river is that produced by urban sewages, application of fertilizers, 
Table 3. Influence of changes in flow of Agrio and Guadiamar rivers on $\mathrm{pH}$ values and contents in Fe, total inorganic solids (t.i.s.), total organic solids (t.o.s.) and suspended inorganic solids (s.i.s.)

\begin{tabular}{|c|c|c|c|c|c|c|c|c|c|c|}
\hline \multirow{2}{*}{$\begin{array}{c}\text { Sampling } \\
\text { site }\end{array}$} & \multicolumn{5}{|c|}{$\begin{array}{l}\text { Low flow } 20 \text { Feb. } 1978 \\
\left(\mathrm{mg} \mathrm{l}^{-1}\right)\end{array}$} & \multicolumn{5}{|c|}{$\begin{array}{l}\text { High flow } 27 \text { Feb. } 1978 \\
\left(\mathrm{mg} \mathrm{t}^{-1}\right)\end{array}$} \\
\hline & $\mathrm{pH}$ & $\mathrm{Fe}$ & t.i.s. & t.o.s. & s.i.s. & $\mathrm{pH}$ & $\mathrm{Fe}$ & t.i.s. & t.o.s. & s.i.s. \\
\hline 1 & 6.5 & 0.10 & 70 & 22 & 10 & 6.7 & 0.20 & 21 & 69 & 7 \\
\hline 2 & 2.8 & 135.5 & 2817 & 647 & 15 & 6.8 & 0.14 & 69 & 404 & 9 \\
\hline 4 & 7.9 & 0.07 & 377 & 97 & 1 & 7.9 & 0.33 & 141 & 662 & 84 \\
\hline 5 & 7.8 & 0.05 & 506 & 105 & 0 & 7.8 & 0.11 & 106 & 379 & 45 \\
\hline 7 & 7.9 & 0.07 & 758 & 160 & 32 & 7.9 & 0.20 & 89 & 343 & 33 \\
\hline \multirow{2}{*}{$\begin{array}{l}\text { Sampling } \\
\text { site }\end{array}$} & \multicolumn{5}{|c|}{$\begin{array}{l}\text { Low flow } 24 \text { Noy. } 1978 \\
\left(\mathrm{mg} \mathrm{l}^{-1}\right)\end{array}$} & \multicolumn{5}{|c|}{$\begin{array}{l}\text { High flow } 26 \text { Jan. } 1979 \\
\left(\mathrm{mg} \mathrm{I^{-1 } )}\right.\end{array}$} \\
\hline & $\mathbf{p H}$ & $\mathrm{Fe}$ & t.i.s. & t.o.s. & s.i.s. & $\mathrm{pH}$ & $\mathrm{Fe}$ & t.i.s. & t.o.s. & s.i.s. \\
\hline 1 & 7.2 & 1.00 & 103 & 29 & 0 & 7.0 & 0.00 & 90 & 64 & 0 \\
\hline 2 & 2.8 & 225.0 & 5248 & 678 & 1 & 7.5 & 0.08 & 295 & 153 & 85 \\
\hline 4 & 8.0 & 0.06 & 532 & 57 & 0 & 7.7 & 0.52 & 198 & 109 & 83 \\
\hline 5 & 7.9 & 0.02 & 931 & 46 & 3 & 7.7 & 0.16 & 214 & 131 & 26 \\
\hline 7 & 8.0 & 1.00 & 3825 & 780 & 0 & $*$ & + & 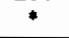 & $\star$ & 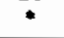 \\
\hline
\end{tabular}

"The access to sampling site was cut off due to floods of the Guadiamar river.

pesticides, etc., which has an important influence on the $\mathrm{N}$ and $\mathbf{P}$ contents of waters. Figure 7 shows the mean values of organic- $\mathrm{N}, \mathrm{NH}_{3}, \mathrm{NO}_{3}$, total- $\mathrm{PO}_{4}$ and dissolved- $\mathrm{PO}_{4}$ contents in sampling sites $6-13$. The corresponding coefficients of variation, not shown here, are in all cases close to $100 \%$.

The mean values of organic- $\mathrm{N}$ and $\mathrm{NH}_{3}$ both in wet and dry periods in sites $9,10,11$ and 13 are very similar to those in site 12 . These results cannot be only due to rice fields being irrigated with waters taken from the Guadalquivir river, since rice is heavily fertilized with ammonium or urea fertilizers. In a previous study (Peris, 1982) it was observed that Sevilla, with a population of 600,000 , originates a remarkable increase in the contents in organic- $\mathbf{N}$ and $\mathrm{NH}_{3}$ of waters of the Guadalquivir river. This pollution decreased gradually downstream and after $10 \mathrm{~km}$ past Sevilla, the values were again similar to those found upstream immediately before the city. At the

Table 4. Heavy metal contents in sediments of sampling sites 24-27

\begin{tabular}{lrrrr}
\hline Sampling site & 24 & \multicolumn{2}{c}{25} & 26 \\
$\left(\mathrm{mg} \mathrm{kg}^{-1}\right)$ & 27 \\
\hline Metal content & & & & \\
$\mathrm{Fe}$ & 36,000 & 31,900 & 35,250 & 11,900 \\
$\mathrm{Cu}$ & 40 & 50 & 40 & 0 \\
$\mathrm{Mn}$ & 660 & 490 & 660 & 90 \\
$\mathrm{Zn}$ & 110 & 11.1 & 100 & - \\
\hline
\end{tabular}

same time the concentration of $\mathrm{NO}_{3}$ increased. In the present work, concentrations of organic- $\mathrm{N}$ and $\mathrm{NH}_{3}$ at site 12 , located approx. $30 \mathrm{~km}$ downstream from Sevilla, are similar to those found by Peris (1982) at $10 \mathrm{~km}$ form the same city. These values are also similar to those found at site 8 in which organic-N and $\mathrm{NH}_{3}$ can only arise from the biotic activity and soil organic matter evolution as this sampling site is located in a canal receiving runoff and drainage water from virgin saline soils under reclamation. Similar results were found by Reinhorn and Arnimeloch (1974). Because of the uniformity of climatic factors and the low content in, well humified, organic matter (approx. 2\%) of the Western Andalusian soils (Martín and González Vila, 1981), it could be inferred that the levels of organic-N and $\mathrm{NH}_{3}$ found in the Guadalquivir river and rice soil drains of the studied zone are those corresponding to the ecological semiequilibrium state and will change only where they receive exogenous effluents.

Figure 8 shows the direct relationship between organic- $\mathrm{N}$ content and rainfall in site 8; only during July 1978 and 1979 organic-N peaks do not correspond with rainfall but are caused by the preceding springtime microbiologic activity. The behaviours of organic- $N$ contents with time in sites 6,7 and 8 exhibit a narrow similarity (Fig. 8; data for site 6 not shown). Therefore, organic-N in sites 6 and 7 , re-

Table 5. Effect of pumping waters from the Guadiamar river into sampling site 10 during spring and autumn of 1978 and 1979 (olive mills and pumps work only in autumn)

\begin{tabular}{|c|c|c|c|c|c|c|}
\hline & \multicolumn{3}{|c|}{ Spring } & \multicolumn{3}{|c|}{ Autumn } \\
\hline & 1978 & 1979 & $\begin{array}{c}\text { Mean } \\
\text { (13 samples) }\end{array}$ & 1978 & 1979 & $\begin{array}{c}\text { Mean } \\
\text { (17 samples) }\end{array}$ \\
\hline $\mathrm{Fe}\left(\mathrm{mg} \mathrm{l}^{-1}\right)$ & 0.05 & 0.11 & $\overline{0.08}$ & 0.17 & 0.11 & 0.14 \\
\hline $\mathrm{Cu}\left(\mathrm{mg} \mathrm{^{-1 }}\right)$ & 0.01 & 0.02 & 0.02 & 0.00 & 0.01 & 0.01 \\
\hline$M n\left(m g ~^{-1}\right)$ & 0.06 & 0.07 & 0.06 & 0.18 & 0.45 & 0.31 \\
\hline $\mathrm{Zn}\left(\mathrm{mg} \mathrm{l}^{-1}\right)$ & 0.03 & 0.04 & 0.03 & 0.05 & 0.17 & 0.11 \\
\hline $\mathrm{K}\left(\mathrm{mg} \mathbf{1}^{-1}\right)$ & 8.0 & 8.5 & 8.3 & 23.4 & 12.7 & 18.4 \\
\hline Dissolved oxygen (mg l-1) & 7.3 & 6.4 & 6.9 & 2.1 & 3.0 & 2.5 \\
\hline PPCC in $\mathrm{O}_{2}\left(\mathrm{mg} \mathrm{l}^{-1}\right)$ & 22.6 & 45.3 & 33.9 & 86.0 & 67.3 & 77.2 \\
\hline
\end{tabular}



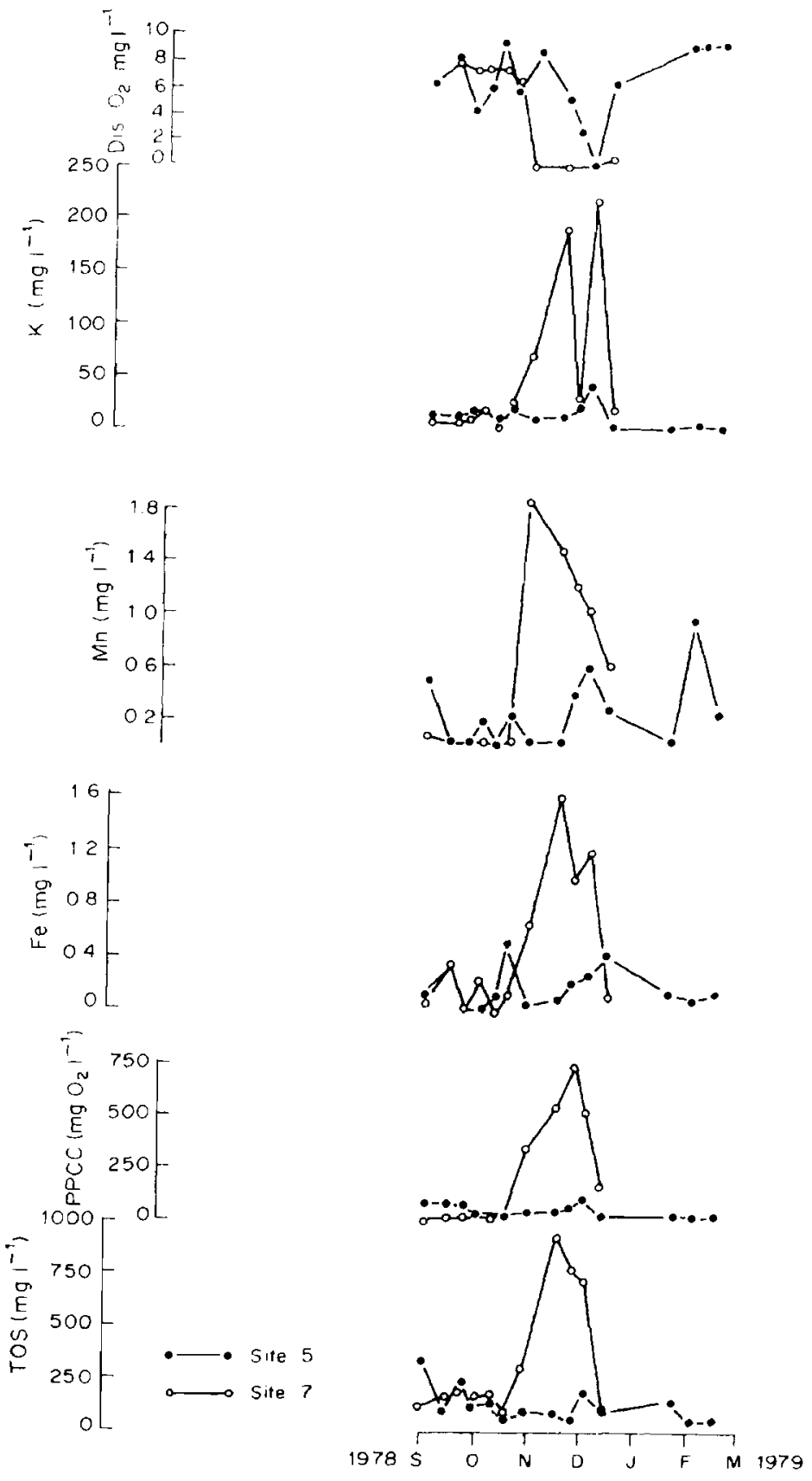

Fig. 6. Variations of dissolved oxygen, total organic solid (t.o.s.), Fe, $\mathrm{Mn}$ and $\mathrm{K}$ contents and potassium permanganate consuming capacity (PPCC) in sampling sites 5 and 7 from September 1978-March 1979.

ceiving village sewages, seems to be more influenced by the evolution of the organic matter of soil than by that of urban origin. The possible influence of village sewages in sites $5,6,7$ and 12 is shown by $\mathrm{NO}_{2}$ contents (Table 6), as large amounts of $\mathrm{NO}_{2}$ are considered as an indication of sewage effluents (Hannan et al., 1973).

The $\mathrm{NO}_{3}$ content in waters from site 12 can be due to the evolution of the organic- $\mathrm{N}$ compounds present in Sevilla sewages, as said before, and also to the leaching of the $\mathrm{NO}_{3}-\mathrm{N}$ fertilizers used in dry-land agriculture in the Guadalquivir valley. The lower
$\mathrm{NO}_{3}$ mean values found in sites $9,10,11$ and 13 show that rice fields behave as $\mathrm{NO}_{3}$ sinks.

Total and dissolved $\mathrm{PO}_{4}$ values in site 7 are high especially in wet period due to the presence of alpechines. This fact can be seen in Fig. 8 in which total- $\mathrm{PO}_{4}$ values in site 7 reach a maximum, $42.6 \mathrm{mg}$ $\mathrm{PO}_{4} \mathrm{I}^{-1}$ corresponding with $\mathrm{K}$ concentrations as high as $218 \mathrm{mg} \mathrm{KI}^{-1}$ (Fig. 6).

Influence of alpechines is also noticed in site 12 although the $\mathrm{PO}_{4}$ values are lower than in site 7 (Fig. 7), what can be explained considering that Guadalquivir river receives olive mill effluents far 


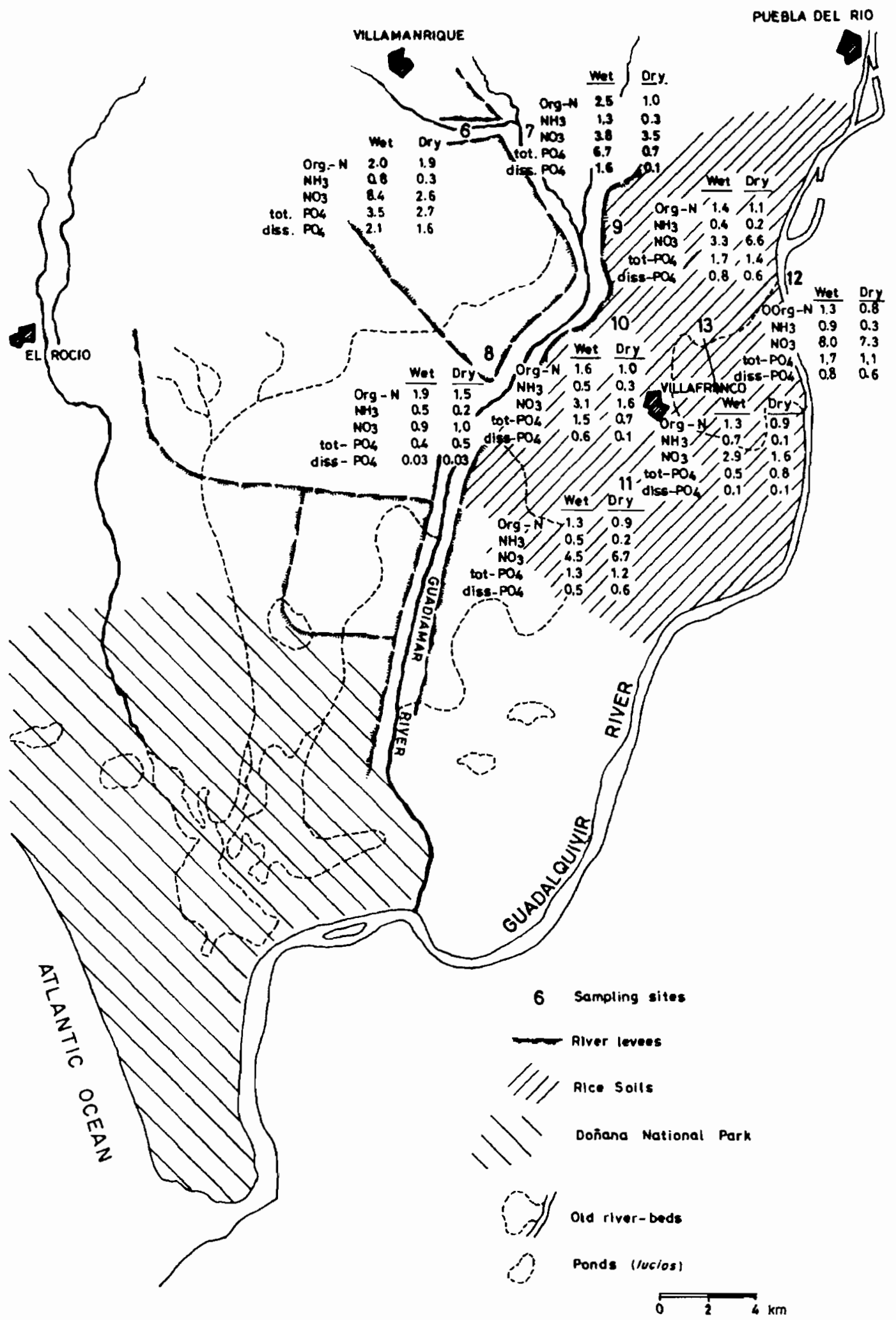

Fig. 7. Mean values of organic- $\mathrm{N}, \mathrm{NH}_{3}, \mathrm{NO}_{3}$, total- $\mathrm{PO}_{4}$ and dissolved- $\mathrm{PO}_{4}$ contents in sampling sites 6-13 during wet and dry periods of 1978 and 1979 (concentrations in $\mathrm{mg} \mathrm{l}^{-1}$ ).

upstream from site 12 and that it carries much more water than the Guadiamar river.

In rice field canals (site 9, 10,11 and 13) total and dissolved $\mathrm{PO}_{4}$ mean values are equal or even lower than those in site 12 . As the main sources of $P$ in the rice fields are fertilizers and irrigation waters from Guadalquivir river (site 12) and occasionally from Guadiamar river (site 7), it can be concluded that rice fields behave as $P$ sinks. Since the first step of the transformation of $\mathbf{P}$ fertilizers in calcareous soils is 

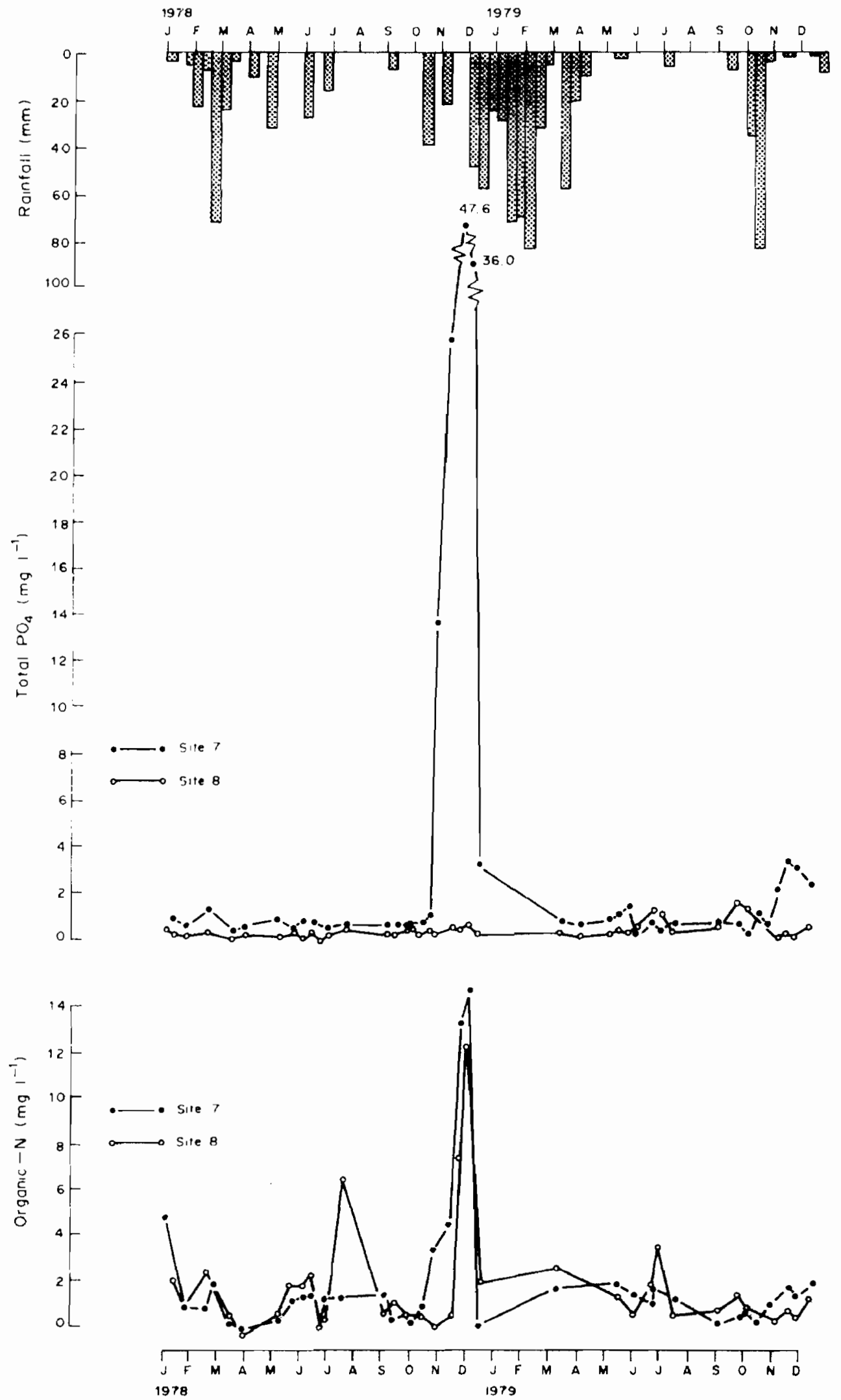

Fig. 8. Variations of rainfall, organic-N and total-PO, in sampling sites 7 and 8 during 1978 and 1979. 
Table 6. Mean, maximum and minimum values of $\mathrm{NO}_{2}^{-}$content in sampling sites 5-13 during 1978 and 1979

\begin{tabular}{|c|c|c|c|}
\hline \multirow{2}{*}{$\begin{array}{l}\text { Sampling } \\
\text { site }\end{array}$} & \multicolumn{2}{|c|}{$\mathrm{NO}_{2}^{-}\left(\mathrm{mg} \mathrm{^{-1 }}\right)$} & \multirow[b]{2}{*}{ Min. } \\
\hline & Mean & Max. & \\
\hline 5 & 0.39 & 5.36 & 0.00 \\
\hline 6 & 0.75 & 2.14 & 0.00 \\
\hline 7 & 0.27 & 4.90 & 0.00 \\
\hline 8 & 0.01 & 2.40 & 0.00 \\
\hline 9 & 0.22 & 2.00 & 0.00 \\
\hline 10 & 0.10 & 5.40 & 0.00 \\
\hline 11 & 0.24 & 2.70 & 0.00 \\
\hline 12 & 0.50 & 2.00 & 0.00 \\
\hline 13 & 0.18 & 1.70 & 0.00 \\
\hline
\end{tabular}

dicalcium phosphate dihydrate releasing approx. $200 \mathrm{mg} \mathrm{PO} \mathrm{P}^{-1}$ to the soil solution (Moreno et al., 1960; Arambarri and Madrid, 1971), $\mathrm{PO}_{4}$ concentration in rice field canals seems to be governed by either the pseudoequilibrium of more insoluble soil phosphates (i.e. octocalcium phosphate) or by hydrolysis of poly and organic phosphates.

On the other hand, mean values of total and dissolved $\mathrm{PO}_{4}$ in site 8 (Fig. 7) have the expected equilibrium values for unfertilized soils in the Guadalquivir valley in which the residual $P$ is in apatite-like forms (Garcia de Leániz and Arambarri, 1975; Madrid et al., 1977).

The dissolved oxygen values in rice field canals are normally high enough for aquatic life, with mean values approx. $7 \mathrm{mg} \mathrm{O}_{2} 1^{-1}$ in wet period and slightly smaller in dry period, approx. 4.9. Only when waters from site 7 are pumped into those canals the dissolved oxygen reaches low values (Table 5).

Table 7 shows the Ordram, 2,4-D and 2,4,5-TP maximum contents in different sites. The 2,4-D and 2,4,5-TP herbicides were found to be ubiquitous along the studied zone, as found by Chacko and Gummer (1980) and in some instances reach values considered as the limit of safety (U.S. EPA, 1977). Pollution by 2,4-D and 2,4,5-TP is bigger in site 30 than in sampling sites 28 and 29 in most occasions, which can be taken as an indication that the polluted waters enter the Donana National Park from south to north in the direction shown by the arrows in Fig. 2.

Ordram concentrations found after application were maximum and similar to those found in the rice fields of Camargue, France (Podlejski, 1978). After-

Table 7. Maximum values found for herbicides contents in rice fields and in the National Park of Donana

\begin{tabular}{ccccc}
\hline $\begin{array}{c}\text { Sampling } \\
\text { site }\end{array}$ & Date & $\begin{array}{c}\text { Ordram } \\
\left(\mathrm{mg} \mathrm{l}^{-1}\right)\end{array}$ & $\begin{array}{c}2,4-\mathrm{D} \\
\left(\mu \mathrm{g} \mathrm{I}^{-1}\right)\end{array}$ \\
\hline 18 & June 1978 & 4.1 & - & - \\
15 & June 1979 & 5.2 & 25.3 & 16.5 \\
17 & June 1979 & 4.5 & 17.2 & 6.3 \\
18 & June 1979 & 2.5 & 47.2 & - \\
28 & July 1979 & ND & 45.5 & 7.1 \\
29 & July 1979 & ND & 47.8 & 10.2 \\
30 & July 1979 & ND & 34.1 & 10.9 \\
\hline
\end{tabular}

ND-not detected. wards the concentration decreases in such a way that this herbicide has not been detected in sites 28-30 in the Doñana National Park (Table 7). Similar results were reported by Soderquist et al. (1977).

\section{CONCLUSIONS}

Drainage waters from polymetallic sulphide deposits and old mine spoil-heaps originate high concentrations of heavy metals in water and sediments of Agrio and Guadiamar rivers. When river flows increase because of heavy rains or reservoir discharges, sediments are resuspended and transported downstream. The presence of other effluents rich in organic matter with active chelating agents (alpechines) facilitate the metal dissolution and transport. Consequently $30 \mathrm{~km}$ downstream from the mine heavy metal concentrations in Guadiamar river are still higher than those in other unpolluted rivers of this zone. The progression of the heavy metal pollution in the Guadiamar river can be prevented controlling the mine effluents and sudden flow increases of Agrio and Guadiamar rivers.

Pollution by olive mill effluents (alpechines) is important during the grinding season (autumn and winter). It originates increases in the $\mathrm{K}, \mathrm{P}$ and organic matter contents of water as well as decreases in dissolved oxygen to levels inadequate for aquatic life. Therefore, discharge of alpechines should not be allowed without a pretreatment whose nature will be established in subsequent research works.

Nitrogen and $P$ fertilization of rice fields is not at the moment producing abnormal increases in the concentration of these elements in water. However, it has been found that concentrations of 2,4-D and 2,4,5-TP in waters of both the rice field canals and Doñana National Park reach in some occasions values considered as the limit of safety for aquatic life. That means that rice fields are not isolated from Doñana National Park so the conditions of fertilizers and pesticides applications must be controlled (e.g. wind direction and velocity must be monitored previous to each application of chemicals by aircraft, and other factors like drain leakage must be avoided).

Acknowledgements - We are grateful to Dr L. Madrid for valuable advice and to Mrs Maruja Soto, Mrs Maria F. Osta, Mr J. Muñoz and Mr E. Martínez-Magro for technical help.

\section{REFERENCES}

Andaluza de Piritas S. A. (1978) Memoria para Accionistas 1977. Sopec/G Internacional, Madrid.

APHA (1971) Standard Methods for Examination of Water and Wastewater, 13th Edition. American Public Health Association, Washington, DC.

Arambarri P. and Madrid L. (1971) Reacción de óxidos de hierro y aluminio con fosfato dicálcico dihidrato. $A n$. Edafol. Agrobiol. XXX, 1083-1094. 
Arambarri P., Gonzalez Garcia F. and Garcia de Leaniz. J. (1969) Interacción de cuatro minerales de la arcilla con ortofosfato monocálcico monohidrato. An. Edafol. Ag robiol. XXVIII, 881-894.

Aubert H. and Pinta M. (1977) Trace Elements in Soil Development in Soil Science No. 7. Elsevier. Amsterdam.

Cabrera F., Diaz E. Toca C. G. and Arambarri P. de (1982) A modification of the hydrogen peroxide method of determination of total phosphorous in natural waters. Water Res. 16, 1061-1064.

Centro de Edafologia y Biología Aplicada del Cuarto (1979) Mapa de Suelos de España. escala 1:400.000. C.S.1.C.. Madrid.

Chacko V. T. and Gummer W. D. (1980) Content and distribution pattern of 2,4-D in the Red river. Technical Bulletin No. 115, Environment Canada.

Fiestas J. A., León R., Garcia A., Fernández de Tejada A. and Sáiz J. (1981) Aplicación de los procesos anaeróbicos en la depuración de aguas residuales industriales con alta carga orgánica. Ingenieria quim. 147, 85-89.

Filipek L. H., Chao T. T. and Carpenter R. H. (1981) Factors affecting the partitioning of $\mathrm{Cu}, \mathrm{Zn}$ and $\mathrm{Pb}$ in boulder coatings and stream sediments in the vicinity of a polymetallic sulfide deposit. Chem. Geol. 33, 45-64.

Garcia de Leániz J. and Arambarri P. (1975) Cambios de los potenciales quimicos del fosfato monocálcico y del hidróxido cálcico en presencia de minerales de la arcilla y fosfatos cálcicos cristalizados. An. Edafol. Agrobiol. XXXIV, 549-567.

Hannan H. H., Young W. C. and Mayhew J. J. (1973) Nitrogen and phosphorus in a stretch of the Guadalupe river. Texas, with Five main-stream impoundments. $\mathrm{HV}$ drobiologia 43, 419-441.

Hutchinson T. C. and Whitby L. M. (1974) A study of airborne contamination of vegetation and soils by heavy metals from the Sudbury. Ontario, copper-nickel smelters. In Trace Substances in Environmental Health (Edited by Hemphill D. D.), pp. 175-178. University of Missouri. Columbia.

Madrid L., Mazuelos C. and Arambarri P. de (1977) Effect of application of magnesium phosphate on the fertilizing value of different calcium phosphates. Phosph. Agric. 71, $1-8$.

Martin F. and González-Vila F. J. (1981) L'oxydation au persulfate des acides humiques du sol. Colloque Humus Azote, Vol. I, pp. 14-18. I.N.R.A., Reims.

Moore J. W. (1980) Distribution and transport of heavy metals in the sediments of a small northern eutrophic lake. Encir. contam. Toxic. 24, 828-833.

Moreno E. C.. Brown W. E. and Osborn G. (1960) Stability of dicalcium phosphate dihydrate. Soil Sci. Soc. Am. Proc. 24, 99-102.

Murphy J. and Riley J. P. (1962) A modified single method for the determination of phosphate in natural waters. Analytica chim. Acta 27, 3!-36.

Nichols K. H. (1975) A single digestion procedure for rapid manual determination of Kjeldahl nitrogen and total pjosphorus in natural waters. Ahathica rhim. dita 76. $21) 8 \cdot 212$.

Norris R. N.. Swain R. and Lake P. S. (1981) Ecological effects of nine effluents on the South Esk river. Northeastern Tasmania. II. Trace metals. Aust. J. Mar. Frobh widt, Rex. 32.

Pagenkopl G. K. and Cameron D. (1979) Deposition of trace metals in stream sediments. Water, Air. Soil Pollat. $11,429-435$

Peris E. (1982) La contaminación en la ria del Guadalquivir en el tramo comprendido entre Alcalá del Rio y la Cortá de la Isleta. Doctoral thesis, Universidad de Sevilla.

Podlejski J. (1978) Les trajtments phytosanitaires des rizieres de Camargue. In Recherches Ecologiauts sur les Rizicres de Carmague (Edited by Heurteaux P.). Ministire des Universités, Direction des Sciences de la Vic du C.N.R.S.

Reinhorn $T$. and Avnimelech $Y$. (1974) Nitrogen release associated with the decrease in soil organic matter in newly cultivated soils. J. envir. Qual. 3, 215-221.

Rodier J. (1981) Análisis de las Aguas. Omega, S.A., Barcelona.

Say P. J. and Giani N. (1981) The Rjou Mort. a tributary to the river Lot polluted by heavy metals. II. Accumulation of zinc by oligochoetes and chironomids. Acta oecologia/oecologia Applic. 2, 339-355.

Scheiner D. (1974) A modified version of the sodium salicylate method for analysis of wastewater nitrates. Water Res. 8, 835-840.

Soderquist C. J., Bowers J. B. and Grosby D. G. (1977) Dissipation of molinate in a rice field. J. agric. Fd Chem. 25, $940-945$.

Solozarno L. (1969) Determination of ammonia in natural waters by the phenolhypochlorite method. Limmol Oceanogr. 114, 799-801.

Stainton M. P., Capel M. J. and Armstrong F. A. J. (1977) The Chemical Analysis of Fresh Water, 2nd Edition. Miscellaneous Special Publication No. 25, Fisheries and Environment, Canada.

Symader W. (1980) Suspended heavy metals: an investigation of their temporal behaviour in flowing waters Catena 7, 1-26.

Thompson J. G. (1980) Acid mine waters in South Africa and their amelioration. Water S.A. 6, 130-134.

U.S. EPA (1977) Qualit! Criteria for Water. Washington, DC.

U.S. EPA (1979) Methods for Chemical Analysis of Water and Wastes. Environmental Monitoring and Support Iaboratory, Cincinnati, $\mathrm{OH}$.

Vanney J. R. (1970) L'Hydrologie du bas Guodalquivir. Instituto de Geografía Aplicada, C.S.I.C., Madrid.

Young G. J, and Blevins R. D. (1981) Heavy metal concentrations in the Holston river basin (Tennessee), Archs envir. contam. Toxic. 10, 541-560.

Zweig G, and Sherma J. (1972) Analytical Methods for Pesticides and Plant Growth Regulators, Vol. VI. Academic Press. New York. 